\title{
Diversity and microbial community in new dark earth soils in Tailândia-Pará, Brazil
}

\section{Diversidade e comunidade microbiana em solos de terra preta nova em Tailândia-Pará, Brasil}

\author{
Sávia Poliana da Silva ${ }^{1 *}$; Diocléa Almeida Seabra Silva ${ }^{1}$; \\ Maria de Lourdes Pinheiro Ruivo²; Ismael de Jesus Matos Viégas; \\ Rosigrêde Lima da Silva'; Pedro Vitoriano de Araújo Júnior ${ }^{4}$; \\ Heráclito Eugênio Oliveira da Conceição ${ }^{3}$
}

\begin{abstract}
Anthropogenic Dark Earth, one of the most fertile soils in the world, often occur in the Amazon region and shows the effect of intensive occupation of land by pre-Columbian indigenous peoples. By studying Dark Earth, it is possible to develop techniques to reproduce its fertility. This study aimed to reproduce Indian Dark Earth through the use of vegetable and animal waste deposited on oxisol and to survey the biodiversity of the microbial community of this "New Dark Earth" (TPN) in the municipality of Tailândia-Pará, Brazil, during the dry and rainy seasons. The experimental design was a randomized block design with 4 replicates, in an area of 3 ' 3 m, with $2 \mathrm{~m}$ separating them. Combinations of coal (C), waste sawdust (RPS), shredded wood blade waste (RLT), bone residue (RA), as well as blood and fat (S) were used for the following treatments: 1 (C), 2 (RPS), 3 (RLT), 4 (RA), 5 (C + RPS), 6 (C + RLT), 7 $(\mathrm{C}+\mathrm{RA}), 8$ (RPS + RLT), 9 (RPS + RA), 10 (RLT + RA), $11(\mathrm{C}+\mathrm{RPS}+\mathrm{RLT}), 12(\mathrm{C}+\mathrm{RLT}+\mathrm{RA}), 13$ $(\mathrm{RPS}+\mathrm{RLT}+\mathrm{RA}), 14(\mathrm{C}+\mathrm{RPS}+\mathrm{RLT}+\mathrm{RA}), 15(\mathrm{C}+\mathrm{RPS}+\mathrm{RLT}+\mathrm{RA}+\mathrm{S}), 16$ (Control), and $17(\mathrm{C}$ + RPS + RA). The bacterial population was higher than the fungal population in the 2 study periods, and the rainy season increased the fungal population. The predominant fungi were of the genus Aspergillus, Penicillium, Sclerotium, Trichoderma. The genus Bacillus and gram-negative bacteria were detected in all treatments. The number of fungal colonies was higher than the number of bacterial colonies.
\end{abstract}

Key words: Amazon, microbiological attribute, seasonality, bacteria, fungi

\section{Resumo}

As Terras Pretas Antropogênicas, um dos solos mais férteis do mundo, ocorrem frequentemente na região Amazônica, sendo o efeito remanescente da ocupação intensiva da terra por grupos indígenas Pré-colombianos. A partir do estudo das terras pretas, é possível desenvolver técnicas para reproduzir uma fertilidade semelhante a essa. Este trabalho teve por objetivo tentar reproduzir a terra preta de índio através do uso de resíduos de origem vegetal e animal depositados sobre Latossolo Amarelo e fazer um levantamento sobre a biodiversidade da comunidade microbiana dessa "terra preta nova" (TPN), no município de Tailândia - PA, no período seco e chuvoso. O delineamento experimental foi o de blocos

\footnotetext{
${ }^{1}$ Discentes de Doutorado da Universidade Federal Rural da Amazônia, UFRA, Belém, PA, Brasil. E-mail: saviapoliana@yahoo. com.br; dioclea@ibest.com.br; rosig_silva@yahoo.com.br

${ }^{2}$ Pesquisadora Dr ${ }^{\mathrm{a}}$ do Museu Paraense Emilio Goeldi, Belém, PA, Brasil. E-mail: ruivo@museu-goeldi.br

${ }^{3}$ Profs. Drs. da Universidade Federal Rural da Amazônia, UFRA. Belém, PA, Brasil. E-mail: ismael.viegas@ufra.edu.br; agroheraclito@yahoo.com.br

${ }^{4}$ Técnico Agrícola e Hidroponista, em Altamira, PA, Brasil. E-mail: pedrojunior8@yahoo.com.br

* Author for correspondence
} 
ao acaso com quatro repetições, em uma área de $3 \times 3 \mathrm{~m}$, com $2 \mathrm{~m}$ de intervalo entre si. Os tratamentos foram: 1 (C), 2 (RPS), 3 (RLT), 4 (RA), 5 (C+RPS), 6 (C+RLT), 7 (C+RA), 8 (RPS+RLT), 9 (RPS+RA), 10 (RLT+RA), 11 (C+RPS+RLT), 12 (C+RLT+RA), 13 (RPS+RLT+RA), 14 (C+RPS+RLT+RA), 15 $(\mathrm{C}+\mathrm{RPS}+\mathrm{RLT}+\mathrm{RA}+\mathrm{S}), 16$ (Testemunha) e 17 (C+RPS+RA), onde: carvão $(\mathrm{C})$, resíduo de pó de serra (RPS), resíduos de lâmina triturada (RLT), resíduos de ossos (RA), sangue e gordura (S). A população bacteriana foi superior à população fúngica nos dois períodos de estudo, sendo que o período chuvoso aumentou a população fúngica. Os fungos predominantes foram os do gênero Aspergillus, Penicillium, Sclerotium, Trichoderma. As bactérias do gênero Bacillus e gram (-) foram encontradas em todos os tratamentos. O número de colônias de fungos foi superior ao número de colônias de bactérias.

Palavras-chave: Amazônia, atributo microbiológico, sazonalidade, bactérias, fungos

\section{Introduction}

Most agricultural soils in the Amazon region are acidic, with low cation exchange capacity (CEC) and low fertility, which render these a limiting resource for the productivity and sustainability of agricultural production systems. There are also small areas of soils with dark coloring, namely, Terra Preta, commonly called "Indian Dark Earth" (Terra Preta do Índio-TPI) or Archaeological Dark Earth (terra preta arqueológica-TPA) (CUNHA et al., 2005; KERN, KÄMPF, 1989; COSTA et al., 2004). These areas of dark land are considered ancient Indian villages and formed unintentionally by preColumbian populations.

This type of soil is complete and extremely self-sustainable for agriculture. These soils can be distinguished from other soils by particular characteristics that are the products of ancient human activities (CUNHA et al., 2009) characterized by high levels of nutrients and organic matter (LEHMANN, 2009), $\mathrm{CaO}\left(1.810 \mathrm{mg} \cdot \mathrm{kg}^{-1}\right), \mathrm{P}_{2} \mathrm{O}_{5}$ $\left(4.900 \mathrm{mg} \cdot \mathrm{kg}^{-1}\right)$, and biological activity compared to adjacent soils. These have a $\mathrm{pH}$ within the range of 5.2 to 6.4 , available $\mathrm{P}$ generally above $250 \mathrm{mg} \cdot \mathrm{kg}^{-1}$, $\mathrm{Zn}$ and $\mathrm{Mn}$ above 200 and $450 \mathrm{mg} \cdot \mathrm{kg}^{-1}$, respectively (FALCÃO; BORGES, 2006), in addition to their high biochar content, which is up to 70 times higher than that of the neighboring soils (GROSSMAN et al., 2010). They also have fragments of pottery and Indian artifacts embedded in the matrix of the surface soil horizons, which led to the terminology Archaeological Dark Earth, which is often used by some authors (KERN; COSTA, 1997). The high fertility of these soils is due to the accumulation of organic materials (e.g., bones, shells, feces, and urine) deposited in the Indian village in prehistoric periods. Costa et al. (2009) argued that pedogenic processes acted extensively on these areas, leading to the incorporation of elements such as calcium, magnesium, phosphorus, zinc, manganese, and copper into the soil.

Biochar is the primary structure between the Indian Dark Earth and the adjacent soils and also constitutes an important fraction of many soils around the world and plays an important role in the global biogeochemical carbon cycle (LIANG et al., 2010). Knowing the date of the formation of this soil identifies the age of agriculture on site. Current knowledge places this date at $>4000$ years. Researchers estimate that one inch of Terra Preta takes at least 10 years to form; however, there is no research to prove the actual dates of formation of the TPA.

An important feature of the TPA is the sustainability of its fertility, and soil microorganisms play a key role in the maintenance of this fertility. TPA soils may display a considerable variety in the distribution of microbial populations (THIES; SUZUKI, 2003). This compartment of organic matter of the soil is directly influenced by biotic and abiotic factors and is therefore a sensitive indicator of changes in the soil (MERCANTE et al., 2008) because it is primarily responsible for the transformation of organic matter, the cycling of nutrients, and the flow of energy in the soil (MOREIRA; SIQUEIRA, 2006). In this sense, 
knowledge of these populations becomes very important because the presence or absence of certain microbes reflects the environmental quality of the ecosystem (GAMA-RODRIGUES et al., 2005). The monitoring of the biological community can serve as a criterion to detect major changes in soil quality (ARAÚJO; MONTEIRO, 2007). This information can contribute to the establishment of a more reliable relationship between land use and sustainability (ALVES et al., 2011).

The microorganisms found in Archaeological Dark Earth soils, mainly fungi and bacteria, are able to synthesize humic substances differently compared to other microorganisms found in adjacent soils (CANNAVAN, 2007), which contributes to soil formation and sustainability. All studies on Indian Dark Earth in recent years have focused on how to use this knowledge by looking at the physical, chemical, and biological processes to recover degraded areas, develop family farms, and create carbon stocks. The Indian Dark Earth displays a high degree of fertility resilience and this phenomenon can be directly related to functional communities, especially the microbial populations involved in the cycling of carbon and nitrogen (TAKETANI; TSAI, 2010).

Recently, some studies have focused on the microbiology of Dark Earth. Previous reports involving Indian Dark Earth have focused on its genetic diversity (GERMANO et al., 2012), microbial community (GROSSMAN et al., 2010; O 'NEILL et al., 2009, TAKETANI; TSAI, 2010; NAVARRETE et al., 2010), and biochar content (LIANG et al., 2010). Research has revealed a distinct microbial community in the Dark Earth. Methods with microbial cultivation and the extraction of DNA from soils have shown a higher microbial diversity and species richness in Dark Earth soils compared to those of reference soils (KIM et al., 2007; O’NEILL et al., 2009; RUIVO et al., 2009; TSAI et al., 2009). KIM et al. (2007) reported that the Dark Earth has about 25\% greater richness of bacterial species compared to pristine forest soil of western Amazonia.

Nevertheless, knowledge on the microbial community in these soils remains insufficient. Based on the previously described features of the Dark Earth, attempts to create the so-called New Dark Earth (TPN) to simulate the Indian Dark Earth and to contribute to the sustainable use of Amazonian soils and the conservation of primary forests have been conducted. Some studies have been conducted to understand both the process of formation of these soils and to reproduce TPA, which can be a big step in the development of agriculture in the region. Thus, the aim of this study was to reproduce Indian Dark Earth through the use of vegetable and animal based materials deposited in the oxisol and to conduct a survey of the biodiversity of the microbial population in TPN, which was created in the dry and rainy seasons in the municipality of Tailândia-Pará, Brazil.

\section{Materials and Methods}

The study was conducted in the municipality of Tailândia (meso-region in Northeast Pará) which is located in the state of Pará, in the microregion of Tomé-Açú in northeastern Pará, approximately $280 \mathrm{~km}$ from Belém and bordered by the following counties: Acará to the north, Ipixúna do Pará to the south, Tomé-Açú to the east, and Mojú to the west. The municipality is located at the geographical coordinates $2^{\circ} 36^{\prime}$ and $3^{\circ} 24^{\prime}$ south latitude and $48^{\circ} 58^{\prime}$ and $48^{\circ} 33^{\prime}$ longitude west. The soils of the county are represented by yellow dystrophic oxisols in their textural phases, ranging from medium to clay, with an undulating topography. The climate of the area is the Ami type of the Köppen classification, with an average annual temperature of $27.9^{\circ} \mathrm{C}$, ranging from $28.4^{\circ} \mathrm{C}$ in December and $27.5^{\circ} \mathrm{C}$ in July. The annual rainfall is approximately $2500 \mathrm{~mm}$, with irregular distribution across 2 seasons, the rainy season, which runs from November to June, and 
a less rainy season, starting from July to October, when the monthly total rainfall is $<100 \mathrm{~mm}$ and can cause water stress (SANGUINO et al., 2007).

The municipality of Tailândia was chosen given that it is one of the largest timber hubs of the country, in which approximately $50 \%$ of the lumber is not used by companies and ends up incinerated or accumulated in inappropriate places. The experiment to reproduce TPA was conducted in oxisol, using randomized complete blocks with 4 replicates using the following materials: carbon (C), waste sawdust (RPS), shredded wood blade waste (RLT), bone residue (RA), and blood and fat (S). Each plot occupied an area of 3 ' 3 m, with 2-m intervals. The waste materials were placed on the ground forming a layer of $15 \mathrm{~cm}$ and after a year of experiment, soil samples were collected to a depth of $0-5 \mathrm{~cm}$ in the dry season (September) and rainy season (March). Treatments consisted of 1 (C), 2 (RPS), 3 (RLT), 4 (RA), 5 (C + RPS), 6 (C + RLT), 7 (C + RA), 8 (RPS + RLT), 9 (RPS + RA), 10 (RLT + RA), 11 (C + RPS + RLT), 12 (C + RLT + RA), 13 (RPS + RLT + RA), 14 (C + RPS + RLT + RA), 15 (C + RPS + RLT + RA + S), 16 (Control), and 17 $(\mathrm{C}+\mathrm{RPS}+\mathrm{RA})$.

To determine the microbiological characteristics, the samples were stored under refrigeration in sterile polyethylene bottles and analyzed for microbial community (bacteria and fungi) at the Laboratory of Microbiology of the State University of Pará. A liquid suspension of microorganisms was obtained for each soil sample. The suspensions were prepared in $250 \mathrm{~mL}$ erlenmeyer flasks in which 10 $\mathrm{g}$ samples of soil were diluted in $90 \mathrm{~mL}$ of sterile water. Thereafter, serial dilutions were performed, in which $1 \mathrm{~mL}$ aliquots of this suspension were transferred to test tubes containing $9 \mathrm{ml}$ of sterile water. Three dilutions were performed for fungi and 5 dilutions for bacteria, with 3 replicates per dilution. To inoculate the bacteria and fungi, the pour plate technique was used, which consists of mixing the diluted suspension with the molten agar (at $45^{\circ} \mathrm{C}$ ) contained in a vial, which was then poured into the basal part of a sterile Petri dish.

After solidification, the plates were incubated for $48 \mathrm{~h}$ for bacteria and 5 days for fungi. Potato dextrose agar (PDA) was used as a growth media for fungi and standard agar was used for bacteria. Tartaric acid ( $0.5 \mathrm{~mL} / 100 \mathrm{~mL}$ medium) was added to the potato agar medium to prevent bacterial growth. After defined incubation periods, the Petri dishes with colonies of fungi and bacteria were observed and developed. The number of colony forming units (CFU) was counted with the aid of a CP-602 model colony counter, in contrast with the opaque medium culture, and expressed as $10^{-3} \mathrm{CFU} / \mathrm{g}$ soil for fungi and $10^{-5} \mathrm{CFU} / \mathrm{g}$ soil for bacteria.

Bacteria were classified according to type and the Gram staining was visualized under a light microscope, in which a small sample of the colony was smeared onto a slide with distilled water. The slide was heat fixed to evaporate water and then the following sequence of reagents was added: crystal violet (1 min), Lugol (1 min), alcohol, and safranin (30 s). After drying, the slides were observed under a microscope.

The dominant fungal colonies were isolated to obtain a pure culture, in which a sample of each colony was transferred to a new Petri plate containing PDA culture medium and further incubated for 5 days. Data were subjected to ANOVA and the means were compared using the Scott-Knott test, with 5\% significance.

\section{Results and Discussion}

The results show significant differences among treatments for the microbial community in the 2 periods. The bacterial population was larger than that of the fungal population (Figures 1a and 1b), regardless of the season. The number of bacteria was generally higher than that observed in the fungi, representing $25 \%-30 \%$ of the microbial biomass (MOREIRA; SIQUEIRA, 2006). This observation may be attributable to the high levels 
of organic matter and microbial activity in Indian Dark Earth or New Dark Earth soils, which results in higher $\mathrm{pH}$ values and favoring the growth of the bacterial population, whereas fungi grow well in acidic environments (ALEXANDER, 1980). Unlike fungi, as shown by Barroti and Nahas (2000), the bacterial population increased because of liming the soil, which increased its $\mathrm{pH}$ level. It is well known that bacteria are present in larger amounts compared to fungi, though being smaller in size (DIONÍSIO, 1996). Nevertheless, cultivation experiments in different Dark Earth soils have shown a predominance of fungal populations compared to bacterial populations (RUIVO et al., 2009).

Figure 1. Microbial community in the dry (a) and rainy (b) season, in different combinations of substrates on TPN, in the municipality of Tailândia-PA. * carbon (C), waste sawdust (RPS), shredded wood blade waste (RLT), bone waste (RA), blood and fat (S), and control (B). *Means followed by the same lowercase and uppercase letter do not differ by the Scott-Knott test $(\mathrm{p}<0.05)$ for fungi and bacteria, respectively.
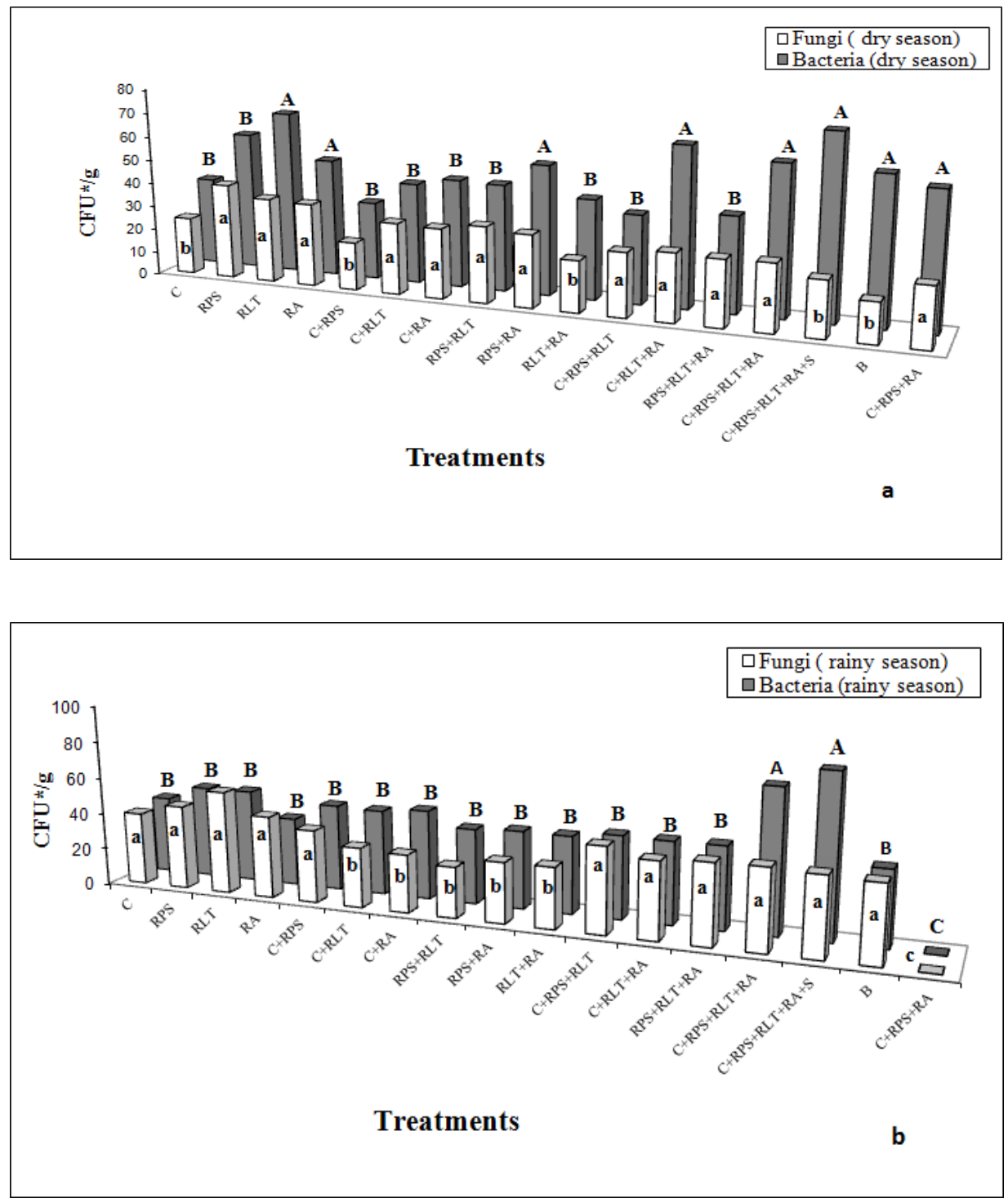

$\mathrm{CV}(\%)_{\text {fungi (dry season) }}=12.63$ and $\mathrm{CV}(\%)$ Source: Elaboration of the authors.

$=9.56 ; \mathrm{CV}(\%)_{\text {fungi (rainy season) }}=11.52$ and $\mathrm{CV}(\%)$ $=7.08$

Source: Elaboration of the authors. 
We can see that the bacterial population underwent less variation (5.03\%) during the dry and rainy seasons compared to the fungal population $(30.15 \%)$. However, the fungal population grew considerably over the collection periods, with an average of $27.04 \mathrm{CFU}^{*} / \mathrm{g}$ in the dry season and 40.00 $\mathrm{CFU}^{*} / \mathrm{g}$ in the rainy season, whereas the bacterial population obtained an average of $51.60 \mathrm{CFU}^{*} / \mathrm{g}$ in the dry season and $49.00 \mathrm{CFU}^{*} / \mathrm{g}$ in the rainy season, with little variation. This fact may be attributable to the increased moisture in the rainy season, inferring that fungi are more sensitive in the absence of water compared to bacteria. Dionísio (1996) investigated soil that was permanently covered with vegetation and observed a marked reduction in levels of fungi during periods of high rainfall. This report explained that a leaching process may have occurred, in which there is a partial removal of soil components that interfere with fungal activity. In relation to the present work, we can infer that this probably did not occur, due to the topography of the terrain, which did not favor erosion or loss of material. However, Rodrigues et al. (2011) conducted studies on humid tropical rainforests and showed that fungi developed better in the dry season and bacteria better in the rainy season, thus contradicting our results.

Ruivo et al. (2006) compared the fungal and bacterial populations in some oxisols and TPA in the Amazon and showed that the moisture content of the soil directly influenced the proportion of bacteria and fungi in the soil. For these authors, the amount of clay was found to influence the ratio.

Considering the heterotrophic nature of fungi, some genera present higher growth during the initial stages of decomposition of the residue applied, with a subsequent decline. However, other genera, such as Aspergillus and Penicillium, which inherently show high sporulation capacity, are readily stimulated by the introduction of an organic substrate, resulting in a high number of colony counts after an extended incubation period (ALEXANDER, 1980).
The identification of bacterial and fungal species in various treatments is shown in Table 1. The predominant fungi included Aspergillus, Penicillium, Sclerotium, and Trichoderma, with percentages of $100,64.70,64.70$, and $41.17 \%$, respectively. The genera Geotrichum, Sporothrix, Rhizopus, Mucor, Eurotium, Phyllosticta, Plectomycetes, and Fusarium were also identified, but at a lower frequency. Amarante et al. (2010) also reported larger amounts of the Aspergillus, Penicillium, and Sclerotium in the Indian Dark Earth and associated their significance to their high number of micelles, which were responsible for soil aggregation, along with exuding organic substances that influenced soil fertility.

The genera Mucor, Rhizopus, Aspergillus, Trichoderma, Penicillium, Fusarium, Pythium, Verticillium, and Alternaria have been reported as the most common microbes in the soil. Reports of the fungal genera Mucor, Fusarium, and Bacillus bacteria have shown that these individuals have positive effects on the reclamation of degraded areas (MOREIRA; SIQUEIRA, 2006), thus suggesting that the reproduction of the Indian Dark Earth may favor the biological recovery of degraded and/or infertile soils for agriculture in the Amazon region.

The number of fungal CFUs was higher than that of bacterial CFUs, with a mean number of 48.35 $\mathrm{CFU}^{*} / \mathrm{g}$ of soil, whereas for bacteria, that value decreased to $8.17 \mathrm{CFU}^{*} / \mathrm{g}$ of soil. The highest incidence of fungal colonies was found in the treatment $(\mathrm{C}+\mathrm{RLT}+\mathrm{RA})$, i.e., a combination of coal with crushed blade waste and bone waste, although not significantly different from the treatments (RPS $+\mathrm{RLT})$ and $(\mathrm{C}+\mathrm{RPS}+\mathrm{RLT}+\mathrm{RA}+\mathrm{S})$ (Figure 2). A higher occurrence of the fungal genera Aspergillus, Rhizopus, Sclerotium (Table 1) was observed with this treatment, with $95 \mathrm{CFU}^{*} / \mathrm{g}$ of the soil (number of colonies), whereas in the treatment (RA) with a lower occurrence of fungi, the genera Aspergillus and Erotium (Table 1) were observed. The number of colonies was $14 \mathrm{CFU}^{*} / \mathrm{g}$ of soil. 
Table 1. Classification of microbial communities in TPN collected from the municipality of Tailândia-PA.

\begin{tabular}{|c|c|c|}
\hline Treatments & Bacteria identified & Fungi identified \\
\hline $\mathrm{C}$ & $\begin{array}{c}\text { Bacillus Gram (-) } \\
\text { Coccus gram (-) }\end{array}$ & $\begin{array}{c}\text { Aspergillus,Fusarium, } \\
\text { Mucor,Penicillium,Sclerotium }\end{array}$ \\
\hline RPS & Bacillus Gram (-) & Aspergillus, Penicillium \\
\hline RLT & Bacillus Gram (-) & Aspergillus, Penicillium, Trichoderma \\
\hline RA & Bacillus Gram (-) & Aspergillus, Erotium \\
\hline $\mathrm{C}+\mathrm{RPS}$ & Bacillus Gram (-) & Aspergillus, Sclerotium,Phyllosticta \\
\hline $\mathrm{C}+\mathrm{RLT}$ & Bacillus Gram (-) & $\begin{array}{l}\text { Aspergillus, Erotium, Mucor, } \\
\text { Sclerotium,Trichoderma }\end{array}$ \\
\hline $\mathrm{C}+\mathrm{RA}$ & Bacillus Gram (-) & $\begin{array}{c}\text { Aspergillus, Geotrichum, Penicillium, } \\
\text { Sclerotium }\end{array}$ \\
\hline RPS + RLT & $\begin{array}{l}\text { Bacillus Gram (-) } \\
\text { Bacillus Gram }(+)\end{array}$ & Aspergillus, Rhizopus, Sclerotium \\
\hline RPS+RA & $\begin{array}{l}\text { Bacillus Gram (-) } \\
\text { Bacillus Gram (+) }\end{array}$ & $\begin{array}{c}\text { Aspergillus, Penicillium, Phyllosticta, } \\
\text { Sclerotium,Trichoderma }\end{array}$ \\
\hline RLT+RA & Bacillus Gram (-) & $\begin{array}{l}\text { Aspergillus, Erotium, Mucor, Penicillium, } \\
\text { Sclerotium,Trichoderma }\end{array}$ \\
\hline $\mathrm{C}+\mathrm{RPS}+\mathrm{RLT}$ & $\begin{array}{l}\text { Bacillus Gram (-) } \\
\text { Bacillus Gram (+) }\end{array}$ & $\begin{array}{l}\text { Aspergillus, Penicillium, Plectomycetes, } \\
\text { Sclerotium, Trichoderma }\end{array}$ \\
\hline $\mathrm{C}+\mathrm{RLT}+\mathrm{RA}$ & Bacillus Gram (-) & Aspergillus, Rhizopus, Sclerotium \\
\hline RPS + RLT + RA & Bacillus Gram (-) & Aspergillus, Penicillium, \\
\hline $\mathrm{C}+\mathrm{RPS}+\mathrm{RLT}+\mathrm{RA}$ & $\begin{array}{c}\text { Bacillus Gram (-) } \\
\text { Bacillus Gram (+) } \\
\text { Coccus Gram (+) }\end{array}$ & $\begin{array}{c}\text { Aspergillus, Erotium, Penicillium, } \\
\text { Trichoderma }\end{array}$ \\
\hline $\mathrm{C}+\mathrm{RPS}+\mathrm{RLT}+\mathrm{RA}+\mathrm{S}$ & $\begin{array}{l}\text { Bacillus Gram (-) } \\
\text { Bacillus Gram }(+)\end{array}$ & $\begin{array}{c}\text { Aspergillus,Sporothrix Penicillium, Sclerotium, } \\
\text { Trichoderma }\end{array}$ \\
\hline B ( control) & $\begin{array}{l}\text { Bacillus Gram (-) } \\
\text { Bacillus Gram (+) }\end{array}$ & Aspergillus, Geotrichum, Mucor, Sclerotium, \\
\hline $\mathrm{C}+\mathrm{RPS}+\mathrm{RA}$ & Bacillus Gram (-) & $\begin{array}{l}\text { Aspergillus, Erotium, Fusarium, Penicillium, } \\
\text { Sporothrix }\end{array}$ \\
\hline
\end{tabular}

Source: Elaboration of the authors.

Aspergillus is widely distributed in nature and may be isolated from a variety of substrates. Due to the ease of dispersion of its conidia and its small size, these can remain suspended in the atmosphere for a long period of time (ABARCA, 2000) and are carried across vast distances by wind (SILVEIRA, 1981), which explains why this genus was found in all treatments that were studied. 
Figure 2. Number of colonies $\left(10^{-3} \mathrm{CFU} / \mathrm{g}\right.$ soil) for fungi and number of colonies $\left(10^{-5} \mathrm{CFU} / \mathrm{g}\right.$ soil $)$ for bacteria. *carbon (C), waste sawdust (RPS), shredded wood blade waste (RLT), bone waste (RA), blood and fat (S), and control (B). *Means followed by the same lowercase and uppercase letter do not differ by the Scott-Knott test $(\mathrm{p}<0.05)$ for fungi and bacteria, respectively.

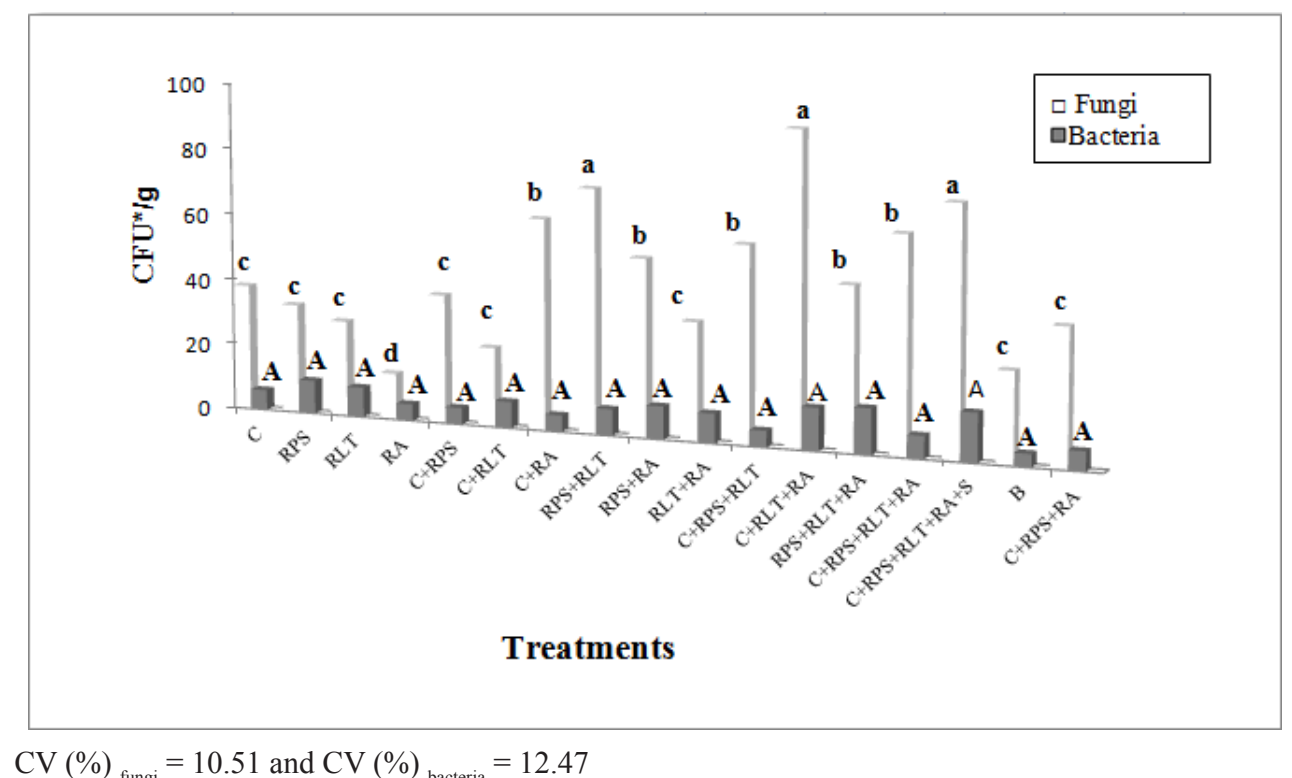

Source: Elaboration of the authors.

Aspergillus is characterized by having a conidiophore with a vesicle (swollen apical end) and stem (cylindrical section located below the vesicle). This is a mitosporic genus, i.e., it experiences asexual reproduction and is characterized by the production of specialized hyphae, called conidiophores, which contain conidiogenous cells that give rise to asexual spores or conidia (ABARCA, 2000).

Penicillium differs from Aspergillus only in the absence of the vesicle; it also presents a conidiophore and stipe. However, its macromorphology, namely the appearance of its colonies, is identical to that of Aspergillus, and it is only possible to differentiate them microscopically. On the other hand, the morphological structure of Sclerotium comprises a web of micelles that contribute to soil aggregation, thus increasing its quality. Its macromorphological structure is characterized by white colonies and a cotton texture (AMARANTE et al., 2010).

We see a higher incidence of bacterial populations in treatment $(\mathrm{C}+\mathrm{RPS}+\mathrm{RLT}+\mathrm{RA}+\mathrm{S})$ in both the dry and rainy seasons, with an average of 76.33 $\mathrm{CFU}^{*} / \mathrm{g}$ of soil and $86.5 \mathrm{CFU}^{*} / \mathrm{g}$ of soil, respectively (Fig. 1a and 1b). The number of colonies found was $15 \mathrm{CFU}^{*} / \mathrm{g}$ soil. The genus Bacillus was found in all treatments, being $100 \%$ Bacillus gram-negative and 41.17\% Bacillus gram-positive. We also observed a negligible presence of gram-positive cocci and gram-negative cocci with treatments $(\mathrm{C}+\mathrm{RPS}+$ $\mathrm{RLT}+\mathrm{RA}$ ) and (C), respectively. Treatment (B) showed the lowest number of colonies, with a value of $4 \mathrm{CFU}^{*} / \mathrm{g}$ of soil and $28 \mathrm{CFU}^{*} / \mathrm{g}$ of soil for bacteria and fungi, respectively.

Bacillus has been described as a genus with great potential to solubilize phosphorus in soils (RODRÍGUES; FRAGA, 1999). The large number of representatives of this genre can be directly associated with a high concentration of phosphorus in substrates used for reproducing dark earth. We can infer that the phosphorus available in this soil type may be more available, due to the significant presence of Bacillus, or because the nutrient is bonded to the available organic matter, which 
does not occur with inorganic linked phosphorus (argilomineriais) where the nutrient is unavailable (MADARI et al., 2009). O’Neill et al. (2009) found an increased number of bacterial populations and diversity, mostly of the Bacillaceae family, in Indian Dark Earth compared to that of adjacent soil.

Bacteria of the genus Bacillus, members of which are generally pathogenic to man, strongly influence co-nodulation of plant roots. Halverson and Handelsman (1991) reported an increase between 30 and 133\% in soybean nodulation by Bradyrhizobium japonicum nativo when the seeds were only treatment with $B$. cereus. The most studied species is $B$. subtilis. This genus produces spores resistant to heat. Bacillus is also recognized as a biological control agent and promoter of plant growth in greenhouses (PAULITZ; BÉLANGER, 2001). Corrêa, Bettiol, and Sutton (2010a) have reported that the addition of $B$. subtilis GB03 twice in the nutrient solution of plants inoculated with the pathogen (Pythium aphanidermatum) increased the mass of the plants by $6 \%$ and increased the chlorophyll content of hydroponic lettuce when applied twice in the nutrient solution not inoculated with the pathogen.

The largest reservoir of Bacillus is the soil. Some species promote plant growth and plant hormone production through the production of siderophores (MELO, 1998), which are organic compounds with a high affinity for iron, an aid in the availability of this element in deficient soils through its sequestering, making it available to plants.

We highlight the presence of fungi of the genus Trichoderma in 7 treatments (Table 1). Trichoderma is a saprophyte organic soil fungus or parasite of other fungi. Several species of fungi of the genus Trichoderma are considered powerful and efficient saprophytes because these act as antagonists of some economically important plant pathogens and also promote the growth of plants. According to Becker and Cook (1988), the mechanisms by which
Trichoderma acts include antibiosis, parasitism, competition, and degradation of the fungal cell wall. Lynck (1992) reported the potential of Trichoderma as a biological agent in agriculture, based on its ability to stimulate plant growth, which promoted an increase from 54 to $100 \%$ in the production of lettuce when incorporated into the compound used in the fertilizer. In response to the application of Trichoderma spp., there were significant increases in the percentage of germination, seedling dry weight, and the leafarea ofpepperplants(KLEIFELD; CHET, 1992). Corn seeds inoculated with Trichoderma harzianum by Resende et al. (2004) resulted in plants with higher dry matter accumulation in roots. Because these are easily formulated and propagated in the laboratory and show good storage capacity (MELO, 1998), Trichoderma has been used in formulating biocontrol products that are marketed in several countries, including Brazil, as is the case with Biotrich. Pathogens of the genus Pythium are among the most important and destructive crop pathogens in hydroponic systems. Severe epidemics caused by $P$. aphanidermatum in hydroponic have been reported when high temperatures prevail in the root zone (SUTTON et al., 2006). Silva (2009), in a pilot study that was conducted in the municipality of Altamira-PA in the Amazon region, reported the efficiency of products based on Trichoderma in nutrient solution in controlling Pythium in hydroponic lettuce production, because the tropical climate was favorable to the attack of this pathogen. This beneficial effect has also been reported in other studies on Trichoderma (ARRIAGADA et al., 2009; HOYOS-CARVAJAL; ORDUZ; BISSET, 2009; PATEKOSKI; PIRES-ZOTTARELLI, 2010; CORRÊA; BETTIOL; MORANDI, 2010b).

The presence of Trichoderma in some treatments with organic material, primarily RLT, and its absence in the control, was shown to influence the levels of specific organic materials that are important for inoculation and soil fertility. 


\section{Conclusions}

The population of fungi in New Dark Earth increased during the rainy season.

The predominant fungi included Aspergillus, as well as Penicillium, Sclerotium, and Trichoderma.

The treatments favored the presence of bacteria of the genus Bacillus and gram-negative bacteria.

The number of fungal colonies was higher than the number of bacterial colonies.

Treatments $(\mathrm{C}+\mathrm{RPS}+\mathrm{RLT}+\mathrm{RA}+\mathrm{S})$ and $(\mathrm{C}$ $+\mathrm{RPS}+\mathrm{RLT}+\mathrm{RA}$ ) favored the high occurrence of the bacterial community.

Treatment $(\mathrm{C}+\mathrm{RPS}+\mathrm{RLT}+\mathrm{RA})$ favored the high incidence of fungal colonies.

\section{Acknowledgments}

The authors thank the CNPq for granting the PhD scholarship.

\section{References}

ABARCA, M. L. Taxonomía e identificación de espécies implicadas en $\mathrm{La}$ aspergilosis nosomical. Revista. Iberoam Micol, Barcelona, v. 17, n. 3, p. 579-584, 2000.

ALEXANDER, M. Introducción a la microbiologia del suelo. México: Libros y Editoriales, 1980. 491 p.

ALVES, T. dos S.; CAMPOS, L. L.; ELIAS NETO, N. ; MATSUOKA, M.; LOUREIRO, M. F. Biomassa e atividade microbiana de solo sob vegetação nativa e diferentes sistemas de manejos. Acta Scientiarum. Agronomy, Maringá, v. 33, n. 2, p. 341-347, 2011.

AMARANTE, C. B. do; RUIVO, M. de L. P.; OLIVEIRA, M. de L. S.; MOURA, Q. L. de. Diversidade microbiana em solos de terra preta arqueológica. Enciclopédia Biosfera, Centro Científico Conhecer-Goiânia, v. 6, n. 11, p. 1-10, 2010.

ARAÚJO, A. S. F. E.; MONTEIRO, R. T. R. Indicadores biológicos de qualidade do solo. Bioscience Journal, Uberlândia, v. 23, n. 3, p. 66-75, 2007.

ARRIAGADA, C.; SAMPEDRO, I.; GARCIAROMERA, I.; OCAMPO, J. Improvement of growth of Eucalyptus globulus and soil biological parameters by amendment with sewage sludge and inoculation with arbuscular mycorrhizal and saprobe fungi. Science of the Total Environment, v. 407, n. 17, p. 4799-4806, 2009.

BARROTI, G.; NAHAS, E. População microbiana total e solubilizadora de fosfato em solo submetido a diferentes sistemas de cultivo. Pesquisa Agropecuária Brasileira, Brasília, v. 35, n. 10, p. 2043-2050, 2000.

BECKER, J. O.; COOK, R. J. Role of siderophores in suppression of Pythium species and production of increased growth response of wheat by fluorescent pseudomonas. Phytopathology, Saint Paul, v. 78, n. 6, p. 778-782, 1988.

CANNAVAN, F. S. Diversidade das comunidades bacterianas em solos de Terra Preta Antropogênica da Amazônia Central e Oriental. 2007. Dissertação (Mestrado em Ecologia Aplicada) - Escola Superior de Agricultura Luiz de Queiroz. Universidade de São Paulo, Piracicaba.

CORRÊA, E. B.; BETTIOL, W.; MORANDI, M. A. B. Controle biológico da podridão de raiz causada por Pythium aphanidermatum e promoção de crescimento de alface hidropônica com Clonostachys rósea. Tropical Plant Pathology, Brasília, v. 35, n. 4, p. 248-252, 2010 b.

CORRÊA, E. B.; BETTIOL, W.; SUTTON, J. C. Controle biológico da podridão radicular (Pythium aphanidermatum) e promoção de crescimento por Pseudomonas chlororaphis 63-28 e Bacillus subtilis GB03 em alface hidropônica. Summa Phytopathol., Botucatu, v. 36, n. 4, p. 275-281, 2010a.

COSTA, J. A.; KERN, D. C.; COSTA, M. L.; RODRIGUES, T. E.; KÄMPF, N.; LEHMANN, J.; FRAZÃO, F. J. L. Geoquímica das Terras Pretas Amazônicas. In: TEIXEIRA, W. G.; KERN, D. C.; MADARI, B. E.; LIMA, H. N.; WOODS, W. As terras pretas de indio da Amazônia: sua caracterização e uso deste conhecimento na criação de novas áreas. Manaus: Embrapa Amazônia Ocidental, 2009. p. 162-171.

COSTA, M. L. da; KERN, D. C.; PINTO, A. H. E.; SOUZA, J. R. da T. The ceramic artifacts in archaeological black earth (Terra Preta) from lower Amazon Region, Brazil: chemistry and geochemical evolution. Acta Amazonica, Manaus. v. 34, n. 3, p. 375-386, 2004.

CUNHA, T. J. F.; MADARI, B. E.; BENITES, V. M.; CANELAS, L. P.; NOVOTNY, E. H.; MOUTTA, R. O.; TROMPOWSKY, P.; SANTOS, G. A. Fracionamento químico da matéria orgânica e características de ácidos húmicos de solos com horizonte A antrópico da Amazônia (Terra Preta). Acta Amazonica, v. 37, n. 1, p. 91-98, 2005. 
CUNHA, T. J. F.; MARADI, B. E.; CANELLAS, L. P.; RIBEIRO, L. P.; BENITES, V. M.; SANTOS, G. A. Soil organic matter and fertility of anthropogenic dark earths (Terra Preta de Índio) in the Brazilian amazon basin. Revista Brasileira de Ciência do Solo, Viçosa, v. 33, n. 1, p. 85-93, 2009.

DIONÍSIO, J. A. Atividades microbianas em diferentes sistemas de cultivo de Eucalipytus grandis (W.Hill Ex Maidnan). 1996. Tese (Doutorado em Ciências Florestais) - Universidade Federal do Paraná, Curitiba.

FALCÃO, N. P. S.; BORGES, L. F. Efeito da fertilidade de Terra Preta de Índio da Amazônia central no estado nutricional e na produtividade do mamão Havaí (Carica papaya L.). Acta Amazônica, Manaus, v. 36, n. 4, p. 401406, 2006.

GAMA-RODRIGUES, E. F.; BARROS, N. F.; GAMARODRIGUES, A. C.; SANTOS, G. A. Nitrogênio, Carbono, e atividade da biomassa microbiana do solo em plantações de eucalipto. Revista Brasileira de Ciência do Solo, Viçosa, MG, v. 29, n. 6, p. 893-901, 2005.

GERMANO, M. G.; CANNAVAN, F. de. S.; MENDES, L. W.; LIMA, A. B.; TEIXEIRA, W. G.; PELLIZARI, V. H.; SIU MUI TSAI, S. M. Functional diversity of bacterial genes associated with aromatic hydrocarbon degradation in anthropogenic dark earth of Amazonia. Pesquisa Agropecuária Brasileira, Brasília, v. 47, n. 5, p. 654-664,2012.

GROSSMAN, J. M.; O'NEILL, B. E.; TSAI, S. M.; LIANG, B.; NEVES, E.; LEHMANN, J.; THIES, J. E. Amazonian anthrosols support similar microbial communities that differ distinctly from those extant in adjacent, unmodified soils of the same mineralogy. Microbial Ecology, New York, v. 60, n. 1, p. 192-205, 2010.

HALVERSON, L. J.; HANDELSMAN, J. Enhancement of soybean nodulation by Bacillus cereus VW 85 in the field and in a growth chamber. Applied and Environmental Microbiology, Baltimore, v. 57, n. 4, p. 2767-2770, 1991.

HOYOS-CARVAJAL, L; ORDUZ, S.; BISSET, J. Growth stimulation in bean (Phaseolus vulgaris L.) by Trichoderma. Biological Control, United States, v. 51, n. 3, p. 409-416, 2009.

KERN, D. C.; COSTA, M. L. Composição química de solos antropogênicos desenvolvidos em Latossolos Amarelos, derivados de lateritos. Geociências, São Paulo, v. 16, n. 1, p. 141-156, 1997.

KERN, D. C.; KÄMPF, N. Antigos assentamentos indígenas na formação de solos com Terra Preta
Arqueológica na região de Oriximiná, Pará. Revista Brasileira de Ciência do Solo, Viçosa, v. 13, n. 2, p. 219225, 1989.

KIM, J. S.; GERD SPAROVEK, G.; LONGO, R. M.; MELO, W. J. de; CROWLEY, D. Bacterial diversity of terra preta and pristine forest soil from the Western Amazon. Soil Biology and Biochemistry, Oxford, v. 39, n. 2, p. 684-690, 2007.

KLEIFELD, O.; CHET, I. Trichoderma: Plant interaction and its effects on increased growth response. Plant Soil, Dordrecht, v. 144, n. 2, p. 267-272, 1992.

LEHMANN, J. Terra preta nova-where to from here? In: WOODS, W. I. (Ed.). Amazonian dark earths: wim sombroeks vision. Berlin: Springer, 2009. p. 473-486.

LIANG, B.; LEHMANN, J.; SOHI, S. P.; THIES, J. E.; O’NEILL, B.; TRUJILLO, L.; GAUNT, J.; SOLOMON, D.; GROSSMAN, J.; NEVES, E. G.; LUIZAO, F. J. Black carbon affects the cycling of non-black carbon in soil. Organic Geochemistry, Bristol, v. 41, n. 2, p. 206213, 2010 .

LYNCK, J. Pesquisa inglesa com agentes biológicos. Journal Agroceres, São Paulo, v. 212, n. 1, p. 2, 1992.

MADARI, B. E.; CUNHA, T. J. F.; NOVOTNY, E. H.; MILORI, D. M. B. P.; MARTIN NETO, L; BENITES, V. M.; COELHO, M.; SANTOS, G. A. Matéria orgânica dos solos antrópicos da amazônia (terra preta de índio): suas características e papel na sustentabilidade da fertilidade do solo. In: TEIXEIRA, W. G.; KERN, D. C.; MADARI, B. E.; LIMA, H. N.; WOODS, W. As terras pretas de índio da amazônia: sua caracterização e uso deste conhecimento na criação de novas áreas. Manaus: Embrapa Amazônia Ocidental, 2009. p. 172-188.

MELO, I. S. de. Agentes microbianos de controle de fungos fitopatogênicos. In: MELO, I. S. de E.; AZEVÊDO, J. L. de. Controle biológico. Jaguariúna: Embrapa-CNPMA, 1998. p. 264.

MERCANTE, F. M.; SILVA, R. F.; FRANCELINO, C. S. F.; CAVAlHEIRO, J. C. T.; OTSUBO, A. A. Biomassa microbiana, em um Argissolo Vermelho, em diferentes coberturas vegetais, em área cultivada com mandioca. Acta Scientiarum. Agronomy, Maringá, v. 34, n. 4, p. 479-485, 2008.

MOREIRA, F. M. S.; SIQUEIRA, J. O. Microbiologia e bioquímica do solo. Lavras: UFLA, 2006. 729 p.

NAVARRETE, A.; CANNAVAN, F. S.; TAKETANI, R. G.; TSAI, S. M. A molecular survey of the diversity of microbial communities in different amazonian agricultural model systems. Diversity, Basel, v. 2, n. 5, p. $787-809,2010$. 
O'NEILL, B.; GROSSMAN, J.; TSAI, S. M.; GOMES, J. E.; LEHMANN, J.; PETERSON, J.; NEVES, E.; THIES, J. E. Bacterial community composition in Brazilian anthrosols and adjacent soils characterized using culturing and molecular identification. Microbial Ecology, Heidelberg, v. 58, n. 1, p. 23-35, 2009.

PATEKOSKI, K. da S.; PIRES-ZOTTARELLI, C. L. A. P. Patogenicidade de Pythium aphanidermatum a alface cultivada em hidroponia e seu biocontrole com Trichoderma. Pesquisa Agropecuária Brasileira, Brasília, v. 45, n. 8, p. 805-810, 2010.

PAULITZ, T. C.; BÉLANGER, R. R. Biological control in greenhouse systems. Annual Review of Phytopathology, Palo Alto, v. 39, n. 2, p. 103-133, 2001.

RESENDE, M. de L.; OLIVEIRA, J. A.; GUIMARÃES, R. G. V. P.; VIEIRA, A. R. Inoculação de sementes de milho utilizando o trichoderma harzianum como promotor de crescimento. Ciência. Agrotécnica, Lavras, v. 28, n. 4, p. 793-798, 2004.

RODRÍGUES, H.; FRAGA, R. Phosphate solubilizing bactéria and their role in plant growth promotion. Biotechnology Advances, Oxford, v. 17, n. 3, p. 319-339, 1999.

RODRIGUES, H. J. B.; SÁ, L. D. de A.; RUIVO, M. de L.; COSTA, A. C. L. da; SILVA, R. B. da; MOURA Q. L. de; MELLO, I. F. de. Variabilidade quantitativa de população microbiana associada às condições microclimáticas observadas em solo de floresta tropical úmida. Revista Brasileira de Meteorologia, São Paulo, v. 26, n. 4, p. 629-638, 2011.

RUIVO M. L. P.; AMARANTE, C. B.; OLIVEIRA, M. L. S.; MUNIZ, I. C. M.; SANTOS, D. A. M. Microbial population and biodiversity in Amazonian Dark Earth soils. In: WOODS, W. I. (Ed.). Amazonian dark earths: wim sombroek's vision. Berlin: Springer, 2009, p. 351362.
RUIVO, M. L. P.; OLIVEIRA, M. L.; LOPES, E. L. N.; AMARANTE, C. B.; GONÇALVES, M. F.; COSTA, R. R.; GUIMARÃES, B. Population ande biodiversity in amazon dark earths soils. In: RIOS, G. M; CAMARGO, S. M. Pueblos y Paisajes antiguos de la. Selva Trapical Amazónica. Colombiana: Universidade Nacional da Colombia, Bogotá-Tara-Xacum/Washington, 2006. p. 284-291.

SANGUINO, A. C.; SANTANA, A. C. de; HOMMA, A. K. O.; BARROS, P. L. C. de; KATO, O. K; AMIN, MMG. Avaliação econômica de sistemas agroflorestais no estado do Pará. Revista de Ciências Agrárias, Belém, v. 47, n. 1, p. 71-88, 2007.

SILVA, S. P. da. Produtividade e concentração de nitrato em cultivares de alface conduzidas em sistema hidropônico, nos municípios de Altamira e Belém, no estado do Pará. 2009. Dissertação (Mestrado em Solos e Nutrição de Plantas) - Universidade Federal Rural da Amazônia, Belém.

SILVEIRA, V. D. Micologia. Rio de Janeiro: Interamericana, $1981.332 \mathrm{p}$.

SUTTON, J. C.; SOPHER, C. R.; OWEN-GOING, T. N.; LIU, W.; GRODZINSKI, B.; HALL, J. C.; BENCHIMOL, R. L. Etiology and epidemiology of Pythium root rot in hydroponic crops: current knowledge and perspectives. Summa Phytopathologica, Botucatu, v. 32, n. 4, p. 307-321, 2006.

TAKETANI, R. G.; TSAI, S. M. The influence of different land uses on the structure of archaeal communities in Amazonian anthrosols based on 16S rRNA and amoA genes. Microbial Ecology, New York, v. 59, n. 4, p. 734743, 2010.

THIES, J.; SUZUKI, K. Amazonian dark earths biological measurements. In: LEHMAM, J.; KERN, D. C.; GLASER, B.; WOODS, W. I. Amazoniam dark earths: origin, properties \& management. Dordrecht: Kluwer Academic, 2003. p. 1-45.

TSAI, S. M.; O’NEILL, B.; CANNAVAN, F. S.; SAITO, D.; FALCAO, N. P. S.; KERN, D. C.; GROSSMAN, J. M.; THIES, J. The microbial world of terra preta. In: WOODS, W. I. (Ed.). Amazonian dark earths: wim sombroek's vision. Berlin: Springer, 2009. p. 299-308. 